\title{
The Effect of Multiple Encounters in Contextualized Learning
}

\author{
MARÍA Jesús SÁNCHeZ \\ Alfredo FernándeZ-SÁnCHEZ \\ University of Salamanca
}

Received: 30 March 2014 / Accepted: 10 May 2015

ISSN: $1697-7467$

\begin{abstract}
The purpose is to detect whether first year university students of English enrolled in an English Study Program benefit from a contextualized vocabulary instruction with only three and six encounters. The research was carried out using the least known terms from the General Service List. As these terms were high in frequency, it was hypothesized that fewer encounters than reported in the literature in the field (Rott, 1999) would suffice. We found suitable authentic contexts in the British National Corpus. In order to find out which type of instruction was more effective (three vs. six encounters), an empirical study with a Pre-test/Post-test design was carried out. We found that with six encounters the benefit was significantly better than with 3 (mean=6.19 vs. 3.13). Nonetheless, a significant difference was found with both types of encounters. This finding has relevant pedagogical implications related to the number of encounters needed by students in order to acquire a high frequency vocabulary. It is advisable to provide a large number of encounters when teaching this type of vocabulary; if it is not possible to expose students to numerous encounters three could be enough, as with three there are substantial gains. The number of encounters is evidently a strategy to be considered when this vocabulary is taught.
\end{abstract}

Keywords: instruction, English as a foreign language, context, high frequency vocabulary, empirical research.

\section{El efecto de múltiples encuentros en una enseñanza contextualizada}

RESUMEN: El propósito es detectar si los estudiantes universitarios de primer curso de inglés, matriculados en Estudios Ingleses, se benefician de una instrucción léxica contextualizada con sólo tres y seis encuentros. La investigación se llevó a cabo con los términos menos conocidos de la General Service List. Dado que estos términos eran de gran frecuencia, se formuló la hipótesis de que con menos encuentros de los que señala la literatura que trata con este tema (Rott, 1999) se produciría aprendizaje. Se utilizaron contextos auténticos procedentes del British National Corpus. Para descubrir qué tipo de instrucción era más eficaz (tres vs. seis encuentros) se llevó a cabo una investigación empírica con un diseño Pre-test/ Post-test. Se encontró que con seis encuentros el beneficio era mucho mayor que con tres (media $=6,19$ vs. 3,13 ). No obstante, se encontró una diferencia significativa con los dos tipos de encuentros. Este hallazgo tiene implicaciones pedagógicas relevantes en relación al número de encuentros que necesitan los estudiantes para adquirir vocabulario de gran frecuencia, siendo aconsejable proporcionar el máximo número de encuentros posibles cuando se enseñe este tipo de vocabulario; si no se puede exponer a los estudiantes a numerosos 
encuentros tres sería suficiente, ya que con esta cifra se producen ganancias sustanciales. El número de encuentros se revela como una estrategia más a considerar cuando se enseña este vocabulario.

Palabras claves: instrucción, inglés como lengua extranjera, contexto, vocabulario de gran frecuencia, investigación empírica.

\section{INTRODUCTION}

The purpose of this lexical research is to provide empirical-based knowledge that can be of practical use to teachers in English language classes. This know-how has to do with issues of relevance for comprehension, speaking and writing that can be crucial if the narrow set of vocabulary that students master in their first years of study is considered. Different studies dealing with lexis have focused on the amount and the type of lexicon that the students of English as a foreign language should command (Nation, 1990; Laufer and Nation, 1995; Meara, Lightbown and Halter, 1997; Hill 2000; Meara and Fitzpatrick, 2000; Nation, 2001; Muncie, 2002; Morris and Cobb, 2004; Horst, Cobb and Nicolae, 2005; Meara, 2005; Pigada and Schmitt, 2006; Coxhead, 2010; Pellicer-Sánchez and Schmitt, 2010). In the last two decades these publications have focused on the importance of lexical learning and discuss relevant aspects in this area. These include the number of words that students should know according to their level, the number of appropriate new terms that should appear in a text, how to measure the lexical richness of texts, etc. These ideas elicit interesting questions regarding the nature of the most frequent lexical entities of the English language and the necessity of mastering this vocabulary at advanced levels, typically found in the university environment.

It is widely known that learning vocabulary in a foreign language is determined by the number of encounters with the words in the input (amount of exposure) and, according to Laufer and Rozovski-Roitblat (2015), also by what students do with the words (task type). Most of the research dealing with vocabulary, as the two previous authors indicate, has examined each aspect separately. Examples of studies for multiple encounters are: Saragi, Nation and Meister (1978), Nation (1982), Jenkins, Stein and Wysoci (1984), Herman, Anderson, Pearson and Nagy (1987), Horst, Cobb and Meara (1998), Waring and Takaki (2007), Webb (2007); some examples for different activities, in which the focus of the research is vocabulary, are the following: Keating (2008), Kim (2008), Pichette, De Serres, Lafontaine (2012). Nonetheless, very few studies (Webb, 2005, Folse, 2006, Lee and Hirsh, 2012) have studied the two aspects together (task/encounters), and conclusions are not clear. In the research conducted by Folse (2006) and Lee and Hirsh (2012) the number of encounters had a stronger effect than the task. However, it was not the same in the research conducted by Webb (2005). Research related to this field is still needed. Therefore, the present study focuses on the number of encounters with the words in the input. It addresses the issue combining the amount of exposure within a class with a contextualized form-focused instruction (Laufer and Rozovski-Roitblat, 2015) and a definition-translation task. The novelty lies in the fact that it happens in a real class context with formal instruction and with fewer encounters than reported in the literature in the field (Rott, 1999), in which students have access to contextualized vocabulary together with lexical explanations. 
In many of the empirical studies with vocabulary learning students are asked to read short texts and then the lexical gain is examined immediately (Zahar, Cobb and Spada, 2001) or also with delayed post-tests (Rott, 1999; Waring and Takaki, 2003). Some other times instead of short texts students are exposed to masses of reading material (Horst, Cobb and Meara, 1998). The most generalized idea transmitted in lexical research is that even more than six encounters are necessary to fully comprehend the terms. Horst, Cobb and Meara (1998) suggested eight encounters. They thought that students should be exposed to masses of reading material to get a large number of ocurrences; Saragi, Nation and Meister (1978) suggested ten encounters, and Jenkins, Stein, and Wysoci (1984) found that $25 \%$ of learners learned a word after 10 encounters. Webb (2007) talked about more than ten encounters for vocabulary learning. Nation (1982) found that a figure of 16 encounters was common in literature. Herman, Anderson, Pearson and Nagy (1987) decided that for full acquisition of a word learners needed 20 encounters. Waring and Takaki (2003) suggested that it could take even more than twenty encounters to learn the meaning of a word. As we can see, estimates of the number of encounters needed to learn vocabulary varies a lot, probably depending on the word (e.g. abstract, concrete, with a high degree of imagineability, etc.), the cognitive process required (recognition or recall), and other different conditions (e. g. level of the students, age, etc.) Although, a consensus has not been reached as to the appropriate number of encounters, it is usually thought: a) that the higher the exposition to vocabulary is the larger the probability of learning it (Jiménez Catalán and Mancebo Francisco, 2008), and also $b$ ) that if repetitions allow to find the words in different contexts the vocabulary will be integrated as part of the students' linguistic repertoire (López-Jiménez, 2014).

Besides the amount of exposure to words, the type of vocabulary students must learn can also be critical to show benefit with different encounters. It is widely assumed that the most frequent words in English are the lexical backbone upon which communication takes place, and in this line Bellomo gives a further step:

Foreign students should first concentrate on high frequency vocabulary. Once these words are adequately understood, students are now ready to learn and apply word attack strategies in order to unlock the meaning of unknown, less frequently occurring words (1999: 3).

Gildner also refers to the importance of learning the most frequent vocabulary, this is what her words reveal: "the instruction that focuses on the most frequent words of English provides students with the largest vocabulary gains possible" (2011: 65). Thus, since frequency plays a very important role in acquisition (Zahar, Cobb and Spada, 2001), even more than contextual richness (Joe, 2010), it is thought that our students should master every word in the General Service List (Bauman and Culligan, 1995) ${ }^{1}$. The vocabulary the students do not know can be taught with suitable authentic contexts taken from the British National Corpus (http://www.natcorp.ox.ac.uk/, a 100-million word collection of samples of written

\footnotetext{
${ }^{1}$ This list was made to supplement West's General Service List (1953), which was thought not sufficiently relevant to the current state of English. Bauman and Culligan used the frequency values from the Brown Corpus (Francis, Kucera and Mackie, 1982) to determine the frequency of words: occurrences of that word and its related forms in the 1,000,000 words of the Brown Corpus. The authors were rigorous enough for someone else, using the same sources and the same criteria, could come up with the same list.
} 
and spoken language from a wide range of sources) with a form-focused contextualized instruction with three or six encounters per word. Six encounters might be enough to learn a word (Rott, 1999); nonetheless, we also explore the possibility of giving a step ahead reducing the number of encounters to three because this high frequency vocabulary will probably produce the same results as the use of more encounters.

Therefore, bearing in mind the literature related to this field and the main purpose of this research, checking the importance of a different number of contexts (different encounters) when teaching and learning vocabulary, two hypotheses were launched:

First of all it was hypothesized that students who saw the terms on six occasions would accrue a better knowledge than the ones who had been exposed to fewer encounters.

As these terms were high frequency vocabulary items it was thought, and therefore hypothesized, that students could learn them with fewer encounters than six (three).

This empirical research intends to rule on whether to use either three or six contextualized encounters for learning high frequency vocabulary. The teaching, with different number of encounters, that is most adequate to the task, will therefore be explored. As a consequence, the effectiveness regarding the number of contexts and the type of instruction, which is more advantageous in the teaching-learning process, will be explored.

\section{Methodology}

\subsection{Procedure}

\subsubsection{Selection of terms and Level test}

Knowledge about high frequency words that our students knew was found through a questionnaire with the words included in the General Service List (Bauman and Culligan, 1995. http://jbauman.com/aboutgsl.html). Freshmen students, belonging to one of the three groups entered for the subject English Language in their first year of English Studies at the University of Salamanca, were asked to rate the General Service List when the second academic semester was finished. The 22 volunteers were instructed to do so using numbers on a Likert scale (grade of familiarity from 1 to 7 ). Number 1 meant that they did not know the word at all. Number 7 meant that they were very familiar with that word. They were told to use all the numbers. The questionnaire was given out in the last 20 minutes of their regular English language class. Due to its length (2,284 words) and the fact that that they had another class afterwards, they were allowed to take the questionnaire home. They were told to give it back to their English Language teacher the day after, and 12 out of the 22 students did so. The answers in the questionnaire provided information about students' knowledge on these terms, and revealed the least known words by our students in the General Service List.

Initial data about the students' knowledge of English (Level Test) was also obtained from the three groups of subjects already mentioned. 


\subsubsection{The study}

In the following academic year (first semester), when we had the ratings of the terms of the questionnaire, necessary for determining the vocabulary to be instructed, we counted on three different groups of students also in their first year. They also took an initial Level Test to check their English knowledge. We conducted a quasi-experimental study, since each of the three groups used in this experiment was randomly assigned to one condition or another; one entire group served as a control group, and the other two served as experimental groups

Once it was checked that there were no significant differences related to English language knowledge, between the three groups in the previous academic year (the ones who rated the General Service List) and the three groups of this experiment, reliability on the ratings done on the General Service List terms was gained. Then an empirical study with a Pre-test/Post-test design with the three groups participating in the experiment was carried out. The purpose was to find out, with first-year English language students, which instruction was more effective with the independent variables (degree of exposure): zero (control: no treatment), three and six encounters (experimental groups).

A definition-translation task with 9 of the chosen terms (Pre-test, see Appendix 1) was used as the dependant variable, and it was done in the first month of class of the academic year. The Post-test (with another 9 terms, see Appendix 1) was administered one month later, once the instruction had been given. When this period of time had passed, the three groups of subjects (from now on named: 0, 3, 6 encounters) wrote again a definition-translation exercise. It was a recall task similar in difficulty to the first one according to two colleagues who had nothing to do with this research (100\% in agreement). We let this amount of time elapse because the purpose of the research was to investigate the effect that the class explanations had over a long period of time. The interest from an educational point of view is to learn what students retain in the long term, which is vital knowledge for obtaining a high level of achievement in the classroom.

One point was assigned for every correct response ( $1 / 2$ a point for the definition and $1 / 2$ a point for the translation into Spanish). We considered both the definition and the translation to be evidence of the students' knowledge of the term and the concept. Mistakes expressing themselves in English were not penalized because at this time the focus was on students' lexical knowledge.

To prevent students from specifically studying this vocabulary rather than learning it through instruction, subjects were told that this lexical material would not be included in their final exam. They were not told, at any moment, that they would have to take a similar test again. Furthermore, in the Post-test participants were asked whether or not they had specifically studied this lexical material in order to analyse the extent to which this influenced the results. The Pre-test and Post-test tasks were done as class exercises and students were not informed that they were participating in an experiment, as we felt that this would maintain their interest and enhance learning with the instruction provided.

\subsubsection{Formal Instruction}

As this lexical material is not easily found within an EFL learning context we provided a form-focused instruction. The teacher explained the terms (18) in the two experimental groups. In one of the experimental groups students had only access to three encounters per 
term, whilst in the other group they had six encounters. As the purpose was to detect changes from the Pre-test to the Post-test in the two experimental groups due to the sort of teaching we had planned to apply in both groups (three encounters/six encounters), a period of class-time was used for the formal instruction of the 18 terms chosen. We used two different teaching sessions (approximately 50 minutes altogether) for the instruction of these terms.

In the first session we spent about 10 minutes to quickly familiarize the students with this vocabulary in the experimental groups. We briefly mentioned differences and similarities, the translation of the terms into Spanish and main situations of use.

In the second session each student in the three-encounter group and in the six-encounter group was given a handout containing different, authentic and brief academic texts ( 3 or 6 ) for each term, extracted from the British National Corpus. During the class time we read the different texts aloud; with this contextualized aid we helped students grasp the meaning or different meanings conveyed by every term (e.g. idle, pad, etc.) We also carried out an exhaustive analysis dealing with the relationships that can be established between the different terms (e.g. steer and stir, sow and scatter, etc.) Students were allowed to look up unknown words in a dictionary in order to comprehend the texts. On some occasions the teacher, who was the same for all the groups, provided different meanings and examples extracted from the WordNet (http://wordnetweb.princeton.edu/perl/webwn), an online lexical reference system whose design is inspired by current psycholinguistic theories of human lexical memory. At other times the teacher made use of example sentences in Spanish as a means of comparison with some specific use in English. This elicited a good number of questions on some concepts. The time of class devoted to this activity was the same in both experimental groups (40 minutes).

Once the instruction had been given, after the Pre-test, a waiting period of approximately three weeks was established for the Post-test. When this period of time had passed the two experimental groups and the control group again took a lexical test similar to the one in the Pre-test.

\subsection{Participants}

\subsubsection{Selection of terms and Level test}

Participants belonging to one of the three groups in the subject English Language enrolled in the first year of English Studies at the University of Salamanca, volunteered to rate the terms in the General Service List. The participants (N=12, 10 females and 2 males) had an average age of 19.1 years. Their data allowed extracting the General Service List terms with the lowest mean.

Students from the three different groups, supposedly with the same knowledge level in English language, took the Level test: $\mathrm{N}=36, \mathrm{~N}=20, \mathrm{~N}=29$ (mean age 19.5, 67 females and 18 males).

\subsubsection{The study}

Students from three different groups, supposedly with the same knowledge level in English language, took the Level test: $\mathrm{N}=22, \mathrm{~N}=32, \mathrm{~N}=31$ (mean age 19.7, 72 females and 13 males) in the following academic year. 
The Pre-test and the Post-test were administered in the following academic year (first semester) also with English Language students. 27, 19 and 26 students participated in the Pre-test and 26, 21 and 26 students in the Post-test. As we were using repeated measures we had to eliminate some of the subjects' tests, because in some cases we only had the Pretest or the Post-test. So we ended up with $\mathrm{N}=19$ (mean age 18.7, 16 females and 3 males), $\mathrm{N}=18$ (mean age 18.9, 14 females and 4 males) and $\mathrm{N}=24$ (mean age 19.3, 17 females and 7 males) participants in each group. The whole group was randomly assigned to 0,3 and 6-encounter group respectively.

\subsection{Materials}

The words used in this research were extracted from the ratings obtained in the questionnaire. We observed that our students were familiar with this frequent vocabulary. In fact, the minimum mean score was 3.17. Therefore, it was thought that it would only be strictly necessary to teach terms whose mean in the questionnaire was below 3.5, in this case 4 terms $(0.17 \%)$. However, it can be a good idea, especially since we have the gradation, to extend this teaching to the terms with a mean below 3.92, in this case 28 words $(1.24 \%)$, to make sure students know more than the superficial form and have several opportunities to come across this vocabulary in different contexts (see the words and the means with a mean below 3.92 in Table 1 below).

Table 1. Mean 3.92 or < in the questionnaire

\begin{tabular}{|l|c|}
\hline \multicolumn{1}{|c|}{ WORDS } & MEAN \\
\hline Idle & 3.17 \\
\hline Beam & 3.25 \\
\hline Grind & 3.42 \\
\hline Vessel & 3.42 \\
\hline Whip & 3.50 \\
\hline Humble & 3.50 \\
\hline Rod & 3.50 \\
\hline Sake & 3.58 \\
\hline Haste & 3.58 \\
\hline Scold & 3.58 \\
\hline Shilling & 3.58 \\
\hline Oar & 3.58 \\
\hline Width & 3.67 \\
\hline Sow & 3.67 \\
\hline Basin & 3.75 \\
\hline Hindrance & 3.75 \\
\hline Beak & 3.75 \\
\hline Saddle & 3.83 \\
\hline Swell & 3.83 \\
\hline
\end{tabular}


Table 1. Mean 3.92 or $<$ in the questionnaire (Cont)

\begin{tabular}{|l|l|}
\hline Bow & 3.83 \\
\hline Steer & 3.83 \\
\hline Pad & 3.83 \\
\hline Stir & 3.92 \\
\hline Scatter & 3.92 \\
\hline Nest & 3.92 \\
\hline Hatred & 3.92 \\
\hline Copper & 3.92 \\
\hline Wreck & 3.92 \\
\hline
\end{tabular}

The criterion followed to decide the terms, which were going to be used to check the benefit of instruction involved choosing the 18 least familiar terms in the General Service List according to students' scores in the questionnaire. The category chosen was verb because this one is more difficult to learn than adjectives, nouns, etc. (Ellis and Beaton, 1993; Singleton, 1997; Sánchez, 2003). Since this is not a complete unknown vocabulary, we could check in a much more thorough way the benefit of instruction with this category of words. Therefore, the terms chosen were: Idle, beam, grind, whip, scold, shilling, sow, beak, saddle, swell, bow, steer, pad, stir, scatter, nest, copper, wreck. On two occasions, with shilling and copper, we had to teach them as nouns because we did not find any contexts in which they were used as verbs, although according to dictionaries they can also belong to the verb category.

The type of instruction that we were planning to teach with this vocabulary was contextualized (three or six encounters) and we got suitable authentic contexts of use in the British National Corpus (see example of 6 contexts with the word wreck).

1. Colour can transform a room or wreck it.

2. If he looks after the car and keeps himself right it'll be okay but if he's gonna mess about and wreck the car well he's no way of getting to work.

3. You wreck the countryside, you wreck the towns, now not content with England you're off to wreck Singapore.

4. First, there are those juveniles who steal and wreck fast cars.

5. The report concluded, however, that the impending Gulf conflict, which was to follow Iraq's invasion of Kuwait in August 1990, could wreck the economies of poor borrower countries by reducing their export volumes while raising fuel import prices and destabilizing lenders.

6. The Philadelphia four-some are terrified that romance could wreck their plans for stardom.

\section{Results}

First of all English language knowledge was checked through the Level test in the six groups to see if they were homogenous groups. All the groups of students $(\mathrm{N}=36, \mathrm{~N}=20$, $\mathrm{N}=29 ; \mathrm{N}=22, \mathrm{~N}=32, \mathrm{~N}=31$ ) took this test. As expected, there were no significant differences 
among the six groups in the first year of English Studies. The homogeneity of the groups was checked by analysing the Level test data using an ANOVA (ANalysis Of VAriance) procedure; the results obtained in this test: $F=1,603(\mathrm{df}=5 / 164), p=0,162$ showed no significant differences. This was done because students in the previous year had rated the material to be used in the research and it could only be used in a reliable way if all the students had a similar knowledge in English language (see Table 2 for descriptive statistics).

Table 2. Descriptive statistics

\begin{tabular}{|l|l|l|l|l|}
\hline Group & Count & Mean & St. Dev. & St. Error \\
\hline Group 1 & 36 & 7.644 & 1.576 & .263 \\
\hline Group 2 & 20 & 7 & 1.43 & .32 \\
\hline Group 3 & 29 & 6.941 & 1.55 & .288 \\
\hline Group 4 & 22 & 7.373 & 1.357 & .289 \\
\hline Group 5 & 32 & 6.988 & 1.475 & .261 \\
\hline Group 6 & 31 & 6.7 & 1.636 & .294 \\
\hline
\end{tabular}

The goal pursued in this research was to detect a significant difference from the Pre-test to the Post-test in the two experimental groups in the dependent variable used (definitiontranslation task). If we can pick up differences, we can affirm that learning has been achieved with this contextualized instruction. To test the hypotheses formulated in this research it was first of all verified that the experimental groups (3/6 encounters) and the control group ( 0 encounters) began with the same knowledge in the requested task. The analyses carried out with the data collected from the three groups $(\mathrm{N}=24, \mathrm{~N}=18, \mathrm{~N}=19)$ in the definition and translation task allowed us to confirm the initial equivalence in this specific vocabulary. As expected, there were no significant differences among these groups in the Pre-test (ANOVA): $F=0,498(\mathrm{df}=2 / 58), p=.6101$ (see descriptive statistics in the table below).

Table 3. Descriptive statistics

\begin{tabular}{|l|c|c|c|c|}
\hline Group & Count & Mean & St. Dev. & St. Error \\
\hline 6-encounter & 24 & .521 & .232 & .047 \\
\hline 3-encounter & 18 & .5 & .569 & .134 \\
\hline 0-encounter (control) & 19 & .632 & .496 & .114 \\
\hline
\end{tabular}

Once the instruction was given, a paired t-test was obtained for every group. The data, as expected, show significant differences in the three and six-encounter group.

6-encounter group: $t(23)=18.146, p=.0001$.

3-encounter group: $t(17)=8.109, p=.0001$

0-encounter group: $t(18)=8.992, p=.0001$

A significant difference was not expected for the control group. Nonetheless, it does not endanger the research. The participants in the 0 -encounter (control) group have matured 
on their own, but the mean in this group is very small (1.36) compared to the experimental groups (6-encounter: 5.66; 3-encounter: 2.63). Students have improved their vocabulary because of its formal classes and all those activities done outside academia along the semester.

Another ANOVA was carried out for the same groups in the Post-test. The results show that there are significant differences between the three groups: $F=67.049,(\mathrm{df}=2 / 58), p=.0001$ (see Table 4 and 5 for descriptive statistics and post hoc comparisons).

Table 4. Descriptive statistics in the Post-test

\begin{tabular}{|l|c|c|c|c|}
\hline Group & Count & Mean & St. Dev. & St. Error \\
\hline 6-encounter & 24 & 6.188 & 1.73 & .321 \\
\hline 3-encounter & 18 & 3.139 & 1.173 & .277 \\
\hline 0-encounter & 19 & 2 & .667 & .153 \\
\hline
\end{tabular}

Table 5. Post hoc comparisons. *Significant at $95 \%$

\begin{tabular}{|l|c|c|}
\hline Comparison & Mean diff. & Fisher PLSD \\
\hline 6 vs 3-encounter group & 3.049 & $.77^{*}$ \\
\hline 6 vs 0-encounter group & 4.188 & $.759^{*}$ \\
\hline 3 vs 0-encounter group & 1.139 & $.812^{*}$ \\
\hline
\end{tabular}

The data all together means that the students in the experimental groups have learnt the high frequency vocabulary taught to them. The participants in the 0 -encounter group have also changed since there is a significant difference from the Pre-test to the Post-test, in this case due to maturation. However, the three and six-encounter group did behave differently from the control group in the Post-test, as can be seen in the mean of each group. The experimental groups have learnt much more with instruction, confirming the benefit of using three different encounters, as a minimum, when teaching high-frequency vocabulary.

\section{Conclusions}

The instruction with the terms chosen that considers a wide number of contexts (at least six) can have very positive results for learning high frequency vocabulary. Students learned more than those who had been exposed to fewer encounters, confirming the first hypothesis.

Nonetheless, results do provide convergent data supporting Rott's study (1999) on foreign vocabulary learning, in which this researcher suggests the necessity of being exposed to at least to six encounters with new words, even though as the literature in the field claims it is not the optimal threshold (Saragi et al., 1978; Nation, 1982; Jenkins et al., 1984; Herman et al., 1987; Horst et al., 1998; Waring and Takaki, 2003; Webb 2007; Joe, 2010). As expected, a significant difference in the vocabulary learning for the group with fewer encounters was produced due to the frequency and familiarity of students with this vocabulary, thus confirming the second hypothesis. Results lead us to interpret that the instruction has been 
successful in the experimental group with three encounters, giving a further step in relation to Rott's findings (1999).

As a continuation and departure point for further research, it should be considered whether a different number of contexts (one or two) would make any difference for learning to occur with recall tasks. One might also consider if the learning gained with the three-encounter group would allow subjects to use this lexical material adequately in more spontaneous and natural conditions and not only in tasks developed within the classroom.

This research will help teachers, from now on, to be sure about the number of times they should practice new words, or partially unknown words, and also to solve problems related to comprehension, speaking and writing tasks because of limitations in vocabulary knowledge. This research will save teachers time as students will not need to be exposed to the target words more than three times in order to learn high frequency vocabulary.

\section{REFERENCES}

Bauman, J. and Culligan, B. (1995). "About the General Service List". http://jbauman.com/ aboutgsl.html, accessed 25 October, 2012.

Bellomo, T. S. (1999). "Etymology and vocabulary development for the L2 college student", in TESL-EJ, 4, 2: 1-7.

British National Corpus, http://www.natcorp.ox.ac.uk/, accessed 17 October 2012.

Coxhead, A. (2010). "Grabbed early by vocabulary: Nation's ongoing contributions to vocabulary and reading in a foreign language", in Reading in a Foreign Language, 22, 1: 1-14.

Ellis, N. and Beaton, A. (1993). "Factors affecting the learning of foreign language vocabulary: Imagery keyword mediators and phonological short-term memory", in The Quarterly Journal of Experimental Psychology, 46A, 3: 533-558.

Folse, S. K. (2006). "The effect of type of written exercise on L2 vocabulary retention", in TESOL Quarterly, 40: 273-293.

Francis, W. N., Kucera, H. and Mackie, A. W. (1982). Frequency Analysis of English Usage. Boston: Houghton Mifflin.

Gilner, L. (2011). "A primer on the General Service List", in Reading in a Foreign Language, 23, 1: 65-83.

Herman, P. A., Anderson, R. C., Pearson, P. D., and Nagy, W. E. (1987). "Incidental acquisition of word meaning from expositions with varied text features", in Reading Research Quarterly, 22: 263-284.

Hill, M. M. (2000). "Words on the web: Taking vocabulary out of the classroom and into cyberspace", in ONLINE-ED Refereed Internet Journal. University of Melbourne, Australia. http://www.edfac.unimelb.edu.au/online-ed/, 5pp., accessed 28 October, 2012.

Horst, M., Cobb, T., and Meara, P. (1998). "Beyond A Clockwork Orange: Acquiring second language vocabulary through reading", in Reading in a Foreign Language, 11: 207-223.

Horst, M., Cobb, T., and Nicolae, I. (2005). "Expanding academic vocabulary with an interactive on-line database", in Language, Learning and Technology, 9, 2: 90-110.

Jenkins, J.R., Stein, M.L., and Wysoci, K. (1984). "Learning vocabulary through reading", in American Educational Research Journal, 21, 4: 767-787.

Jiménez Catalán, R. and Mancebo Francisco, R. (2008). "Vocabulary input in EFL textbooks", in RESLA, 21: 147-165. 
Joe, A. (2010). "The quality and frequency of encounters with vocabulary in an English for academic purposes programme", in Reading in a Foreign Language, 22, 1: 117-138.

Keating, G. D. (2008). "Task effectiveness and word learning in a second language. The involvement load hypothesis on trial", in Language Teaching Research, 12: 365-386.

Kim, Y. (2008). "The role of task-induced involvement and learner proficiency in L2 vocabulary acquisition", in Language Learning, 58: 285-325.

Laufer, B. and Nation, P. (1995). "Vocabulary size and use: Lexical richness in L2 written production", in Applied Linguistics, 16, 3: 307-322.

Laufer, B. and B. Rozovski-Roitblat, B. (2015). "Retention of new words: Quantity of encounters, quality of tasks, and degree of knowledge", in Language Teaching Research, 19, 6: 687711. DOI: $10.1177 / 1362168814559797$

Lee, Y-T. and Hirsh, D. (2012). "Quality and quantity of exposure in L2 vocabulary learning," in D. Hirsh (ed.), Current Perspectives in Second Language Vocabulary Research. Bern: Peter Lang, 79-116.

López-Jiménez, M. D. (2014). "A critical analysis of the vocabulary in L2 Spanish textbooks", in Porta Linguarum, 21: 163-181.

Meara, P. (2005). "Lexical frequency profiles: A Monte Carlo analysis", in Applied Linguistics, 26, 1: 32-47.

Meara P. and Fitzpatrick, T. (2000). "Lex30: An improved method of assessing productive vocabulary in an L2", in System, 28, 1: 19-30.

Meara, P., Lightbown, P. M., and Halter, R. H. (1997). "Classrooms as lexical environments", in Language Teaching Research, 1, 1: 28-47.

Morris, L. and Cobb, T. (2004). "Vocabulary profiles as predictors of TESL student performance", in System, 32, 1: 75-87.

Muncie, J. (2002). "Process writing and vocabulary development: Comparing lexical frequency profiles across drafts", in System, 30, 2: 225-235.

Nation, I. S. P. (1982). "Beginning to learn a foreign vocabulary: A Review of the Research", in RELC Journal, 13, 1: 14-36.

(1990). Teaching and Learning Vocabulary. Boston: Heinle and Heinle Publishers. (2001). Learning Vocabulary in Another Language. Cambridge: Cambridge U. P.

Pellicer-Sánchez, A. and Schmitt, N. (2010). "Incidental vocabulary acquisition from an authentic novel: Do Things Fall Apart?" in Reading in a Foreign Language, 22, 1: 31-55.

Pichette, F., De Serres, L., and Lafontaine, M. (2012). "Sentence reading and writing for second language vocabulary acquisition", in Applied Linguistics, 33: 66-82-

Pigada, M. and Schmitt, N. (2006). "Vocabulary acquisition from extensive reading. A case study", in Reading in a Foreign Language, 18, 1: 1-28.

Rott, S. (1999). "The effect of exposure frequency on intermediate language learners' incidental vocabulary acquisition and retention through reading", in Studies in Second Language Acquisition, 21: 589-619.

Sánchez, M. J. (2003). "Importancia de la composición de los campos semánticos en su aprendizaje", in Miscelánea, 27: 229-248.

Saragi, T., Nation, P., and Meister, G. (1978). "Vocabulary learning and reading", in System, 6: 72-80.

Singleton, D. (1997). "Learning and processing L2 vocabulary", in Language Teaching, 30, 4: 213-225.

Waring, R. and Takaki, M. (2003). "At what rate do learners learn and retain new vocabulary from reading a graded paper?" in Reading in a Foreign Language, 15, 1-27. 
María Jesús SÁnchez and Alfredo Fernández-SÁnchez $\quad$ The Effect of Multiple Encounters...

Webb, S. (2005). "Receptive and productive vocabulary learning", in Studies in Second Language Acquisition, 28: 46-65.

(2007). "The effects of repetition on vocabulary knowledge", in Applied Linguistics, 28: 46-65.

West, M. (1953). A General Service List of English Words. London: Longman.

WordNet, http://wordnetweb.princeton.edu/perl/webwn, accessed 18 November, 2012.

Zahar, R., Cobb, T., and Spada, N. (2001). "Acquiring vocabulary through reading: Effects of frequency and contextual richness", in Canadian Modern Language Review, 57, 4: 541-573. 


\section{APPENDIX 1. PRE-TEST}

LAST NAME

NAME

Define the following terms and translate them into Spanish:

1. Idle

2. Wreck

3. Beam

4. Copper

5. Grind

6. Nest

7. Whip

8. Scatter

9. Scold

\section{APPENDIX 1. POST-TEST}

LASTNAME NAME

Define the following terms and translate them into Spanish:

1. Shilling

2. Stir

3. Sow

4. Pad

5. Beak

6. Steer

7. Saddle

8. Bow

9. Swell 